\title{
CARNATION WILT DISEASES CAUSED BY FUNGI IN FINLAND
}

\author{
E. A. Jamalainen and Laina Ruotsalainen \\ Department of Plant Pathology, Agricultural Research Centre, Tikkurila
}

Received August 20, 1961

The wilting disease of carnation (Dianthus caryophyllus L.) is caused by bacteria and fungi, among which the most often encountered are the Fusarium-fungi, Phialophora cinerescens (Wr.) van Beyma (syn. Verticillium cinerescens Wr.), and the bacteria Pectobacterium parthenii Starr. var. dianthicola Hellm. and Pseudomonas caryophylli (Burkh.) Starr. \& Burkh. (cf. Scholten 1955, Hellmers 1958, Pape 1964). For the carnation pathogenic form of F. oxysporum (Schl.) Sn. \& H. has been given the name F. oxysporum (Schl.) Sn. \& H. f. dianthi (Prill. \& Delacr.) Sn. \& H.

\section{Material}

In 1967-68 the Department of Plant Pathology studied the wilting disease of carnation in Finland. Preliminary results have already been published (Ruotsalainen 1969). In order to find out about the occurrence of the disease and the fungi causing it, enquiry forms were sent to 120 carnation growers, and in addition, samples were collected from a number of nurseries. Samples were received from a total of 51 nurseries (Table 1).

The fungi were isolated from the diseased plants by sterile cutting of samples onto oatmeal agar from the root, the base, and from a healthy looking part some $20-30 \mathrm{~cm}$ above the base and from the cut surfaces. From a total of 81 plants 177 isolations were made, and from these, 17 species of funcus were identified (Table 2).

The Fusarium fungi, of which there were 10 species, proved to be the most commonly occurring in carnations infected with wilting diseases. The most common was $F$. oxysporum, which represented $31.1 \%$ of the isolated fungi. Other spesies common were $F$. arthrosporioides, $7.3 \%, F$. avenaceum, $10.7 \%, F$. culmorum, $8.5 \%$, and Alternaria tenuis, $7.9 \%$, as well as Cladosporium sp., $9.0 \%$. Two samples of P. cinerescens, $1.1 \%$, were found. Some fungi of the Penicillium, Aspergillus and other genera occurred as epiphytes, and do not appear in Table 1. 
Table 1. Nurseries from which the carnation samples were taken, from $1967-68$.

\begin{tabular}{|c|c|c|c|c|c|c|c|c|c|c|c|c|c|c|c|c|c|}
\hline Nursery & Locality & 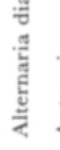 & 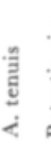 & 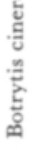 & 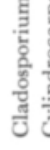 & 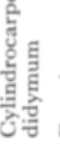 & 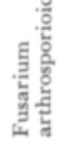 & 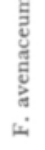 & 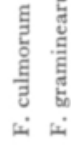 & 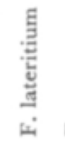 & 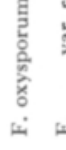 & 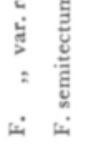 & 矛 & 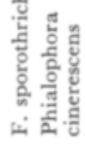 & 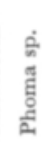 & 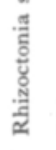 & \\
\hline & & 1 & 2 & 3 & 4 & 5 & 6 & 7 & 89 & 10 & 111 & 1213 & 14 & 1516 & 17 & 18 & $19:$ \\
\hline Ahopellon puutarha & Imatra & & 2 & & & & & & & & 2 & & & & & & \\
\hline Bjomaan $\quad$, & Helsinki & & & & 1 & & & & & & 1 & & & & & & \\
\hline Aackas-tilan , , & Helsingin mlk & & 1 & 1 & 2 & & 2 & & 11 & & 1 & & & & & 1 & \\
\hline Ekengrenin , , & Hamina & & & & & & & & 1 & & 2 & & & & & & \\
\hline Elomaa & Turku & & & 1 & & & & 1 & & & & & & & & & \\
\hline Holmberg & Sipoo & & & & & & & & & & 1 & & & & & & \\
\hline Huhtamäen puutarha & Laihia & & & & 1 & & & & & & & & & & & & \\
\hline Huhtasen $\quad$, & Rauma & & & & 1 & 1 & & & 11 & & & & & & 1 & & \\
\hline Huiskula Oy & Maaria & & & & & & & & & & 2 & & & & & & \\
\hline Ilpoisten kauppapuutarha & Turku & & & & & & & & & & 1 & & & & & & \\
\hline Jaalan puutarha & Raisio & & & & 1 & & & & 1 & & 1 & & 1 & & & & \\
\hline Kaarnikon kauppapuutarha & Turku & & 1 & & & 1 & 1 & 1 & 1 & & 1 & & & & & & \\
\hline Kangaspunta & Helsingin mlk & & & 1 & 2 & 1 & & & & & 1 & & & & & 1 & \\
\hline Kempeleen puutarhurikoulu & Kempele & & & & & & 1 & 1 & & & 1 & & & & & & \\
\hline Koski, Janne & Kokemäki & & & & 1 & & 1 & & & & 1 & & & & & & \\
\hline Koskinen, Toivo & Helsinki & & & & & & & 1 & & & 4 & & & & & & \\
\hline Kukkolan puutarha & Tampere & 1 & & 1 & & & & & 1 & & 2 & & & & & 1 & \\
\hline Lahtelan , , & Kangasala & & 1 & & & & & & & & 3 & & & & & & \\
\hline Lepolan kauppapuutarha & Maaria & & & & & & & 1 & & & & & & 1 & & 1 & \\
\hline Liikkasen puutarha & Hamina & & 1 & & & & & & & & 1 & & & & & & \\
\hline Lindberg, E & Kerava & & & & & & & 1 & & & & & & & & & \\
\hline Loimaan ev. kansanopisto & Loimaa & & 1 & & & & & & & & 1 & & & & & & \\
\hline Lyyvaara, Jali & Turku & & & & & & & & & & 1 & & & & & & \\
\hline Mattila, Ensio & Kangasala & & & & & & & 3 & & & 3 & & & & & & \\
\hline Mattilan puutarha & Orimattila & & & 1 & & & 1 & & & & 2 & & & & & & \\
\hline Naakan $\quad$, & Anjala & & 1 & & & & & & & & & & & & & & \\
\hline Narinen, Matti & Mussalo & & & & 1 & & & & & & & 1 & & & & & \\
\hline Nyystilä, Arvo & Toijala & & & & & & & 1 & & & & & & & & & \\
\hline Olsson, E & Kymi & & & & & 1 & & & & & 1 & & & & & & \\
\hline Pekonen & Lahti & & & & 2 & & 1 & & & & 2 & & & & & & \\
\hline Peuralinna & Helsingin $\mathrm{mlk}$ & & & & & & & & & & & & & 1 & & & \\
\hline Pitkäniemen sairaalan puut. & Nokia & & & & & & & 1 & 2 & & 2 & & & & & & \\
\hline Poukan puutarha & Laitila & & & & & & & 1 & & & 2 & & & & & 1 & \\
\hline Puutarhantutkimuslaitos & Piikkiö & & 1 & & & & & & & & & & & & & & \\
\hline Pyhtään kauppapuutarha & Pyhtää & & & 1 & & & & & & & & & & & & 1 & \\
\hline Rapilan puutarha & Laihia & & & & 1 & & & & 2 & & 1 & & & & & & \\
\hline Reitkallin puutarhakoulu & Vehkalahti & & & & & & & & & & 1 & & & 1 & & 1 & 1 \\
\hline Salmen puutarha & Kivijärvi & & & & & & & & & & 1 & & & & & & \\
\hline Salmi, Esko & Vanaja & & & & & & & & 1 & & 1 & & & & & & \\
\hline Satakunnan parantolan puut. & Harjavalta & & 1 & 1 & 1 & & & & & & & & 1 & & & & \\
\hline Satoturve Oy & Tuusula & & & & & & 1 & 1 & & & & & & & & & \\
\hline Siikin puutarha & Imatra & & & & & & & & 1 & & & & & & & & \\
\hline Sjöberg, Stig & Helsingin mlk & & 2 & & & & 1 & 1 & 1 & & 1 & & & & & & \\
\hline Sjölund, H. V. & Helsingin mlk & & & & & & & 1 & & & 1 & & & & & & \\
\hline Suutari, V. A. & Karhula & & 1 & & & & 1 & 4 & 1 & & 4 & & & & & 1 & \\
\hline Tiihonen ja K:ni & Kausala & & 1 & 1 & & & & & & & 1 & & 1 & & & & \\
\hline Tyynelän puutarha & Punkasalmi & & & & & & 1 & & 1 & 1 & 3 & & & & & 1 & 3 \\
\hline Uutela & Helsingin mlk & & & 1 & & & 1 & & & & & & & & & & \\
\hline Valkeaniemen puutarha & Forssa & & & & 2 & & 1 & & 1 & & 1 & 1 & & & & & \\
\hline Vesan $\quad, \quad$ Oy & Pori & & & 1 & & & & & & & 1 & & & & & & \\
\hline Tuntematon & & & & & & & & & & & & & & 1 & & & \\
\hline
\end{tabular}


The studied material revealed relatively few samples of $P$. cinerescens, the occurrence of which has already been established in Finland (TAlvia 1964-1967). This fungus has been found also in many other countries. In Sweden P. cinerescens was very rare in 1968, while the Fusarium species have been common, in particular F. oxysporum (SöDERGREN 1968, von WAGHeNFelt 1968). In Bulgaria, the main fungi causing diseases in carnation in recent years have been $F$. roseum Link (syn. F. graminearum Schwabe) and F. oxysporum Schl. f. sp. dianthi (Prill. \& Delacr.) Snyder \& Hansen (Aleksandrova 1968). In Holland there was widespread occurrence of F. oxysporum in 1966 (Scholten 1966).

In cuttings and young growing plants the Fusarium fungi cause brown, wet and soft rot in the lowest parts of the stem. The roots are decomposed or not formed at all. The rot is generally confined to the base of the stem, but it may also spread well up to the top

Table 2. Fungi isolated from carnation samples.

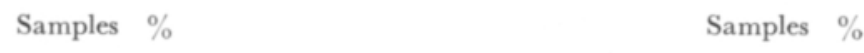

Alternaria dianthi Stev. \& Hall.

A. tenuis Neerg.

Botrytis cinerea Pers. ex Fr.

Cladosporium sp.

Cylindrocarpon didymum (Hart.) Wr.

Fusarium arthrosporioides Sherb.

$F$. avenaceum (Fr.) Sacc.

F. culmorum (W. G. Sm.) Sacc.

F. graminearum Schwabe

F. lateritium (Nees) Sn. \& H.

F. oxysporum (Schl.) Sn. \& H.

$\begin{array}{rr}1 & 0.6 \\ 14 & 7.9 \\ 10 & 5.9 \\ 16 & 9.0 \\ 4 & 2.3 \\ 13 & 7.3 \\ 19 & 10.7 \\ 15 & 8.5 \\ 3 & 1.7 \\ 1 & 0.6 \\ 55 & 31.1\end{array}$

F. oxysporum (Schl.) Sn. \& H. var. redolens (Wr.) Gordon

F. semitectum Berk. \& Rav.

F. solanti (Mart.) Sn. \& H.

F. sporothrichioides Sherb.

Phialophora cinerescens (Wr.) y, Beyma 2

Phoma sp.

Rhizoctonia solani Kühn

Rhizopus sp.

Stemphylium sp.

parts of young plants. If infection has been weak, the pith in the cross section of the stem is brown, once infection has developed further, however, the whole stem becomes rotten and hollow. In older plants the rot is dry (Scholten 1955, Hellmers 1958). Wilting caused by $F$. oxysporum occurs together with collar-fusariosis caused by several other Fusarium species. In these instances it is difficult to distinguish between these diseases without pure cultures. In collar-fusariosis the base of the stem has rotted, while wilting caused by $F$. oxysporum is systemic. Both diseases bring about wilting and loss in yield. $F$. oxysporum is more destructive than other Fusarium fungi owing to the fact that it may penetrate the roots of the carnation in soil. Other Fusarium species penetrate the carnation only through the cut surfaces of the cuttings, through torn parts of older plants, through damaged places in roots and stems, and in particular through the surfaces where branches have been cut off or where the flowers have been cut or broken off (Pape 1964).

Plants damaged by $P$. cinerescens wilt gradually. The wilting leaves turn yellow (straw coloured) and often curl up somewhat. A cross-section of the stem, taken $20-40 \mathrm{~cm}$ from the soil surface, shows a clear brown ring to have developed within the bark. The roots remain healthy and do not come off if the plant is pulled up from the soil (Scholten 1955, Hellmers 1958).

The largest amount of fungi, totalling 15 species, was isolated from the base of the stem. There were missing Cylindrocarpon didymum, which is a typical root pathogen, Alter- 
naria dianthi, which has been found higher up in the stem, and $F$. sporothrichioides and Phoma sp. which were revealed by cross-section of the stem. The species found in all parts of the plant were Botrytis cinerea, $F$. arthrosporioides, $F$. avenaceum, $F$. culmorum, $F$. oxysporum and Rhizoctonia solani. $R$. solani causes stem rot in conditions unfavourable for carnation growing (GuBA 1945, PAPE 1964). The carnations had been infected by A. tenuis, B. cinerea, Cladosporium sp., F. oxysporum. F. sporothrichioides and Phoma sp. through cut surfaces. With a couple of exceptions, Fusarium fungi were found in all the greenhouses (Table 1).

\section{Inoculation trials}

I noculation through soil. The rooted carnation cuttings used in the test were inoculated two weeks after planting with fungus suspension, with which the soil was sprayed. The trial comprised 36 carnation-plants. The results were as follows:

$$
\begin{array}{cc}
\text { Number of wilted plants } \\
\text { after } 8 \text { weeks }
\end{array}
$$

$\begin{array}{lll}\text { Alternaria tenuis } & 0 & 0 \\ \text { Fusarium avenaceum } & 0 & 0 \\ \text { F. culmorum } & 0 & 0 \\ \text { F. oxysporum a } & 0 & 0 \\ \quad " \text { b } & 4 & 6 \\ \text { Control } & 0 & 0\end{array}$

Two different isolates, a and b, of $F$. oxysporum were used in the test. Of all the fungi used, only the b-isolate of $F$. oxysporum was able to destroy the carnations through the soil and to cause their complete wilting within three months.

I noculation from the a ir. The carnations used in the test were 6 months old. After being cut to lengths of $0.5 \mathrm{~m}$ they were inoculated directly by spraying the cut surfaces with fungi suspension. The wilting appeared as shrinking of the stem, wilting and yellowing in the cut internodes, progressing in some branches downwards through several internodes. In healthy cut surfaces the stem was green and fresh. The results were as follows:

\begin{tabular}{lcccc} 
& $\begin{array}{c}\text { No. of cut } \\
\text { stems }\end{array}$ & \multicolumn{3}{c}{ Wilting percentage after } \\
& & 3 weeks & 6 weeks & 8 weeks \\
Alternaria temuis & 21 & 5 & 81 & 81 \\
Fusarium avenaceum & 24 & 4 & 83 & 88 \\
F. culmorum & 21 & 62 & 81 & 81 \\
F. oxysporum & 21 & 19 & 100 & 100 \\
Control & 41 & 0 & 15 & 29
\end{tabular}

All the tested fungi were able to penetrate the plants through their broken surfaces, or to cause in that way at least partial wilting. Most injurious was $F$. oxysporum. Even in the control, which had not been inoculated, wilting began to take place in $29 \%$ of the cut stems. From these Rhizopus sp. was isolated. 


\section{Control trials}

The fungicide-sprays used in the control of the wilt disease caused by $F$. oxysporum were Dithane M-45 (mancozeb $80 \%$ ), Orthocide 50 (captan $50 \%$ ), and Pomarsol Forte (thiram $80 \%$ ). The soil had been inoculated as in the previous trial with the isolate $F$. oxysporum $b$. The first spraying was carried out two weeks after inoculation and was then repeated at fortnightly intervals. The following results were obtained $(\mathbf{D}=$ Dithane M-45, O = Orthocide 50, $\mathrm{P}=$ Pomarsol Forte):

\begin{tabular}{lcccc}
\multicolumn{3}{c}{ Sprayings } & & \multicolumn{2}{c}{ Wilted $\%$} \\
$22 / 7$ & $5 / 8$ & $19 / 8$ & $9 / 8$ & $23 / 8$ \\
& & & 50 & 100 \\
D & D & D & 50 & 91 \\
O & O & O & 41 & 91 \\
P & P & P & 45 & 86 \\
D & O & D & 59 & 95 \\
D & P & D & 59 & 95 \\
O & P & O & 68 & 95 \\
D & O & P & 55 & 86 \\
Inoculated control & & &
\end{tabular}

The sprayings had no effect and the treated plants wilted just as rapidly as the inoculated plants that had not been treated. This is due to the fact that $F$. oxysporum penetrates the wood vessels and the fungicides give the plants only surface protection. The healthy control plants and the non-inoculated treated carnations remained healthy throughout the trial.

Since it was possible that systemic fungicides might protect the plants from the inside, a trial was arranged with these compounds. One batch of carnations was sprayed with fungicides 24 hours before soil inoculation with $F$. oxysporum, another batch 24 hours after. The systemic fungicides used were Benlate (1-(butylcarbamoyl)-2-benzimidazole carbamic acid, methyl ester $50 \%$ ), Plantvax (2,3-Dihydro-5-carboxanilido-6-methyl1,4-oxathiin-4,4-dioxide) and Vitavax (2,3-Dihydro-5-carboxanilido-6-methyl-1,4oxathiin), and in addition the non-systemic fungicide Pomarsol Forte (thiram $80 \%$ ). The results are presented below $(\mathrm{a}=$ advance control, $\mathrm{b}=$ subsequent control):

\begin{tabular}{|c|c|c|c|c|c|c|}
\hline & & & & ing per & & \\
\hline & & $26 / 3$ & $2 / 4$ & $4 / 4$ & $14 / 4$ & $21 / 4$ \\
\hline Vitavax & a & 0.0 & 21.4 & 67.9 & 82.1 & 92.9 \\
\hline$"$ & b & 0.0 & 25.0 & 60.7 & 89.3 & 96.4 \\
\hline Plantvax & a & 7.2 & 78.6 & 96.4 & 96.4 & 100.0 \\
\hline$"$ & b & 3.6 & 75.0 & 96.4 & 100.0 & 100.0 \\
\hline Benlate & a & 0.0 & 50.0 & 100.0 & 100.0 & 100.0 \\
\hline$"$ & b & 3.6 & 28.6 & 85.7 & 92.9 & 100.0 \\
\hline Pomarsol Forte & a & 0.0 & 14.3 & 64.3 & 78.6 & 92.9 \\
\hline$"$ & b & 0.0 & 14.3 & 57.1 & 78.6 & 96.4 \\
\hline Inoculated cont & & 0.0 & 42.9 & 78.6 & 92.9 & 92.9 \\
\hline Non-inoculated & control & 0.0 & 0.0 & 0.0 & 0.0 & 0.0 \\
\hline
\end{tabular}


The systemic fungicides had no effect whatever, and within less than two months over $90 \%$ of the treated plants and the inoculated non-treated plants had withered. The non-inoculated control was at the time completely healthy. There were no differences between the trial plants that had been sprayed 24 hours before and those sprayed 24 hours after the inoculation of the soil.

In another trial it was also planned to determine whether pre-planting treatment with fungicides would protect the cuttings from wilting disease. For this purpose rooted carnation cuttings were kept overnight in F. oxysporum suspension. Subsequently, some of the cuttings were placed in Benlate-solution and the other in Dithane M-45-solution for periods of varying length. After treatment, they were planted in the usual way. The following results were obtained:

\begin{tabular}{|c|c|c|c|c|c|c|c|}
\hline \multirow[t]{2}{*}{ Treatment } & \multirow{2}{*}{$\begin{array}{l}\text { No. of } \\
\text { plants }\end{array}$} & \multicolumn{6}{|c|}{ No. of wilted plants } \\
\hline & & $26 / 2$ & $17 / 3$ & $24 / 3$ & $29 / 3$ & $8 / 4$ & $21 / 4$ \\
\hline Benlate $10 \mathrm{~min}$. & 6 & 1 & 3 & 5 & 6 & & \\
\hline$" \quad 30 \mathrm{~min}$ & 6 & 1 & 4 & 4 & 6 & & \\
\hline$" \quad 60 \mathrm{~min}$ & 6 & 1 & 2 & 6 & & & \\
\hline " 24 hours & 6 & 0 & 0 & 0 & 0 & 3 & 5 \\
\hline \multicolumn{8}{|l|}{ Dithane M-45 } \\
\hline $10 \mathrm{~min}$ & 6 & 0 & 4 & 5 & 6 & & \\
\hline $60 \mathrm{~min}$ & 6 & 0 & 0 & 0 & 6 & & \\
\hline$" \quad 24$ hours & 6 & 0 & 0 & 1 & 3 & 6 & \\
\hline Untreated & 11 & 0 & 11 & & & & \\
\hline
\end{tabular}

In the trial, all the treatments had somewhat delayed the onset of wilting. The untreated lot had wilted completely only one month after inoculation. At the time the plants that had received 24 hours' Benlate treatment and those that had had 60 minutes of Dithane M-45 treatment were completely healthy. While the plants that had been treated with Dithane M-45 for 24 hours had wilted completely in two months' time, of the plants that had been subjected to 24 hours' Benlate treatment, one half was still healthy. In conclusion, the spraying of rooted cuttings prior to planting with systemic fungicides and mancozebcompound delayed wilting to a certain extent.

\section{Su $m$ m a ry}

From 81 carnation samples collected in 1967-68 from nurseries in different parts of the country were identified 17 species of fungus, from a total of 177 fungus isolates. Among these, Fusarium oxysporum was most widespread, $31.1 \%$. F. arthrosporioides, F. avenaceum, F. culmorum, Alternaria tenuis and Cladosporium sp. occurred in considerable quantities. The percentage of Phialophora cinerescens was $1.1 \%$.

In the inoculation trials $F$. oxysporum behaved as a strongly pathogenic, infecting plants via the air through cut surfaces and via the soil by root-penetration. A tenuis, $F$. avenaceum and $F$. culmorum infected carnations only from the air through cut surfaces.

In the fungicide trials against $F$. oxysporum, spraying the plants infected via the soil proved ineffective. The trials were made with the systemic Benlate (1-(butylcarbamoyl)2-benzimidazole carbamic acid, methyl ester $50 \%$ ), Plantvax (2,3-Dihydro-5-carboxanilido-6-methyl-1,4-oxathiin-4,4-dioxide), Vitavax (2,3-Dihydro-5-caboxanilido-6-me- 
thyl-1,4-oxathiin), and with the non-systemic Dithane M-45 (mancozeb $80 \%$ ), Orthocide 50 (captan $50 \%$ ) and Pomarsol Forte (thiram $80 \%$ ).

The dipping of rooted cuttings into Benlatē and Dithane M-45 compounds to a certain extent delayed the process of wilting.

Acknowledgements. Miss Annikki Hyvönen participated in the study in 1967 and Dr. A. Ylimäki was consulted as an expert in the determination of the isolated fungi. The authors wish to thank them for their help.

\section{LITERATURE}

Aleksandrova, I. 1968. Bolesti po Karamfila Sim. Gradinarstvo 10(8): 18-21. (Ref. Rev. Appl. Mycol. 47: 628.)

GubA, E. F. 1945. Carnation wilt diseases and their control. Bull. Mass. Agric. Exp. Sta. 427: 1-64.

Hellmers, E. 1958. Four wilt diseases of perpetual-flowering carnation in Denmark. 200 p. Copenhagen.

PAPE, H. 1964. Krankheiten und Schädlinge der Zierpflanzen und ihre Bekämpfung, p. 333-341. Berlin.

Ruotsalainen, L. 1969. Neilikan lakastumistaudista. Puutarha-Uutiset 21:601-603.

Scholten, G. 1955. Wilting diseases of carnations in the Netherlands. Reprinted from the Report of the XIVth Intern. Horticult. Congress, Netherlands 1955, p. 995-1002.

-»- 1966. Vaatziekten in Anjers. Jaarverslag Proefstation voor de Bloemisterij in Nederland de Aalsmeer, p. $32-34$.

SöDERgRen, W. 1968. Om sjukdomar på växthuskulturer 1967. Växtskyddsnotiser 33: 8-13.

TAlviA, P. 1964-67. Kasvitautien esiintyminen v. 1963. Maatal. ja Koetoim. 18(1964): 194-201. Kasvitautien esiintyminen v. 1964. Ibid. 19(1965): 232-238. Kasvitautien esiintyminen v. 1965. Ibid. 20(1966): 214-221. Kasvitautien esiintyminen v. 1966. Ibid. 21(1967): 214-223.

WACHENFELT, M-A, von. 1968. Exempel på svampsjukdomar i Mellansverige 1967—68. Växtskyddsnotiser 32: $64-72$.

\section{SELOSTUS}

\section{SIENTEN AIHEUTTAMA NEILIKAN LAKASTUMISTAUTI SUOMESSA}

\section{E. A. Jamalainen ja Laina Ruotsalainen}

\section{Kasvitautien tutkimuslaitos, Tikkurila}

Vuosina 1967-68 tutkittiin Kasvitautien tutkimuslaitoksella neilikan lakastumistautia Suomessa, josta on esitetty alustavia tuloksia (RUOTsALAINEN 1969). Tutkimusta varten kerätyistä 81 neilikkanäytteesta määritettiin 17 sienilajia, yhteensä 177 sienieristyksestä. Näistä oli eniten Fusarium oxysporumia, $31.1 \%$. Runsaasti oli myös $F$. arthrosporioidesta, $F$. avenaceumia, $F$. culmorumia, Alternaria tenuista ja Cladosprorium sp:tä. Phialophora cinerescensiä oli $1.1 \%$.

Infektiokokeissa saastutti $F$. oxysporum voimakkaasti patogeenisena kasveja sekä maasta että ilmasta. $A$. tenuis, $F$. avenaceum ja $F$. culmorum saastuttivat neilikoita vain ilmasta haavapintojen kautta.

Fungisidiruiskutukset eivät tehonneet $F$. oxysporumia vastaan tällä saastutetussa maassa kasvavissa neilikoissa. Kokeiltavina olivat systeemiset valmisteet Benlate (metyyli-1-(butyylikarbamoyyli)-2-bentsimidatsolikarbamaatti), Plantvax (2,3-dihydro-5-karboksianilido-6-metyyli-1,4-oksatiini-4,4-dioksidi) ja Vitavax (2,3-dihydro-5-karboksianilido-6-metyyli-1,4-oksatiini) sekä ei-systeemiset valmisteet Dithane M-45 (mankozebi), Orthocide 50 (kaptaani) ja Pomarsol Forte (tiraami).

Juurrutettujen pistokkaiden kastelu sekä Benlate- että Dithane M-45-valmisteella viivästytti jossain määrin lakastumista. 